\title{
How can power discourses be changed? \\ Contrasting the 'daughter deficit' policy of the Delhi government with Gandhi and King's transformational reframing
}

\author{
Manisha Sinha and Des Gasper \\ Prefinal version of a 2009 paper that appeared in Critical Policy Studies, vol.3 \\ (3\&4), 290-308. A version is also available as ISS Working Paper 493, \\ http://repub.eur.nl/res/pub/19672/
}

\begin{abstract}
:
Social policy impact is partly determined by how policy is articulated and advocated, including which values are highlighted and how. We examine the influence of policy framing and reframing on outcomes, with particular reference to policies of the Delhi state government in India that target the practices of female feticide, infanticide and neglect that underlie the 'daughter deficit'. Using Snow and Benford's categories for understanding reframing processes, the paper outlines and uses a 'model' of reframing disputed issues, derived from looking at two famous campaigns - Gandhi's 1930 Salt March in the struggle for Indian freedom from British rule and the African-American civil rights struggle of the 1950s and 60s. It argues that 'carrot and stick' policy measures, such as financial incentives and legal prohibitions, to counteract the 'daughter deficit' must be complemented by well crafted discursive interventions.
\end{abstract}

\footnotetext{
'No matter what people might say, at heart everyone wants a son. Imagine the plight of a couple who has two daughters in a row. Life in the Punjab is cruel for those with too many daughters' (A Village Head from Punjab) (http://unwantedgirlchild.blogspot.com/2008/03/family-planning-promotes-female.html)

'...the strategies that are appropriate under decision-making conditions of severe structural distortion and inequality are restructuring strategies' (Forester 1989, p. 60).
} 


\section{Introduction}

Social issues are often seemingly intractable because they involve a part of the cultural identity of a people. They can derive from long established collective frames of belief and be rooted in political and economic power relations. Social policymakers, whether inside or outside government, may find themselves not only trying to change the status quo with respect to the issue immediately at hand but also unknowingly or not deliberately grappling with deeply entrenched power discourses. The crux of many a failure in social policy lies in the 'unknowingly or not deliberately'; to show sustained impact the policymaker may need to engage deliberately with the underlying power discourse.

For an ordinary policymaker, such deliberative engagement is fraught with difficulties. Much has been written about interpretive policy analysis and discourse theory, but such literature may not be easily accessible for policymakers and they typically lack time to read it or even awareness that it exists. Yet without understanding of the predominant frames around the issue and of the discourses supporting the frames, the policymaker cannot consciously engage and try to modify them. His or her efforts are likely to be a hit and miss affair, with results dependent on luck.

This paper analyses the role of deliberate, informed use of discursive power in seeking to shape social policy outcomes and change fundamental power equations. ${ }^{i} \mathrm{We}$ examine the policy to counter 'daughter deficit' in the metropolis of Delhi, capital of India, in comparison to a hypothesized 'model' that we derive from the successful use of discursive power in two famous movements, one combatting a racist power system (the civil rights movement in the USA) and the other an entrenched imperial-colonial system (Gandhi's strategy in India's liberation struggle). From reflection on the modest outcomes in the Delhi case and by identifying the deliberate discursive elements that are present or absent in that case in comparison to the successful 'model' cases, we offer some ideas on how chances of impact can vary depending on the skill of use, or otherwise, of discursive elements in policy framing.

Each of these three cases is a huge subject in itself. Thus no attempt is made to give a comprehensive picture of any of them and only the elements most salient to the 
paper's core theme are elaborated upon. To help to formulate a 'model', the civil rights movement and the Indian freedom movement are each represented by one seminal event:- the 'I have a dream' speech by Martin Luther King Jr. and the Salt March campaign of Gandhi. Together they convey two aspects - text and action - of discourses that could help to change existing power equations.

\section{Framing and re-framing}

Policies almost invariably have to work outside policymakers' area of control. There are so many independent stakeholders and uncontrolled important factors that policy must become in large part a process of creative thinking about how to exert influence, rather than exercise control, and a social process of trying to build sufficient acceptance and agreement. Often, policymakers focus on the immediate symptoms of a policy issue, without conscious reference to the background power discourses and framing. However, in the standard 'carrots, sticks, and sermons' classification of policy tools-in other words, positive incentives, prospective punishments, and attempted persuasion (Bemelmans-Videc et al. 1998) - 'sermons' may essay re-framing. So too do these possible additions to the list: dialogue and unconditional support (Rem and Gasper 2008).

'Carrots and sticks' covers incentives of many types, since there are many types of motive: through money and markets; through law; through praise and criticism (as in 'naming \& shaming'), and through other forms of conditionality. The 1870 Female

Infanticide Act in India instituted naming and shaming as the first stage of counteraction: 'the public proclamation of guilty clans and villages' (Bedi 2008, p. 16). Each of the types of incentive has possible limitations and side-effects. Conditionality, for example, often fails over the long-term for reasons summarised by Ellerman (2006): it can reduce cooperative spirit and the felt autonomy and self-reliance of the targeted person/organisation; it externalises rather than internalises motivation, weakens independent commitment, and even transfers felt ownership away from the targeted and across to the setter of conditions. Unconditional support, in contrast, can sometimes reframe a relationship by displaying trust and respect. 
'Sermons' and dialogue refer to the provision and exchange of information and arguments. Without these, 'carrots and sticks' alone may have perverse and/or unsustainable effects. Schemes in India to offer financial support for girls' education and marriage might not improve the independent valuation given to girls, and could conceivably even reinforce an orientation to financial calculation of 'the value of a girl'. Interpretive policy analysis literature includes attention to inspirational and potentially unifying formats, as in cooperative scenarios building, human rights-based approaches and 'appreciative inquiry', which is the joint study of areas of success; also to the messages embodied in impressive personal and illustrative examples; and to the use of fora for dialogue, even so-called 'transformative public dialogue' as in Truth and Reconciliation Commissions, and for policy-maker listening to build credibility and legitimacy as well as to learn. Central in all this discursive work is the framing and reframing of issues.

A 'frame' is a mental construct that simplifies and organises complex phenomena into a connected system of meaningful categories, through an act of interpretation involving selective inclusion and exclusion of elements, based on perceptions of relevance. Thus frames focus and structure attention and organize meaning-making. Snow and Benford (1988, p. 198) describe framing as the 'production of meaning'.

The concept of 'frame' was introduced in the 1950s by Gregory Bateson in psychology. It became more widely popular later from the work of Erving Goffman, who defined frames as 'schemata of interpretation' enabling individuals to 'locate, perceive, identify and label' phenomena in a meaningful manner (Goffman 1974, p. 21). These ideas were picked up, used and adapted in many disciplines, from psychology and sociology to management and public policy. The specification of an existing policy issue can be seen as outcome of a particular way of framing. It is sometimes policymakers' task to influence, even transform, that frame in order to promote a different outcome. One cannot, however, simply invent a socially influential new frame; one must relate to and work with existing culturally powerful resources, amongst other constraints. But unless one recognises the re-framing agenda one is unlikely to make progress. Otherwise policy design can become stifled by the weight of causal analysis that refines explanation of the interlocking and, of course, sufficient determinants of the status quo. 
Every social policy issue is a constructed reality, derived from a particular way of constituting knowledge, a particular method of creating meaning. If the way of constructing knowledge or meaning could be changed, so too could the social issue. However, if the construction of knowledge lies too far back in the past or too well internalised, the possibility of reconstruction could be overlooked completely or treated as blasphemy. Further, the definition of the social issue is not just an outcome of a particular way of intellectually constructing reality; it will typically reflect and support particular power relations.

Social issues are not confined to a way of thinking but become tangible in the form of social practices that reflect and reinforce the constructions of meaning. Indeed, the people following the social practices may be adhering to them without explicitly referencing or validating the frames through which the beliefs that underlie the practices are constructed. In the case of especially powerful discourses such as those of gender it may then be important for a policymaker to try to separate the two elements-frames and practices - and try to reframe ideas in order to influence the social practices. However, social policymakers sometimes focus attention and efforts on changing the social practices without seeing the need to address the perceptions that ground the practices.

All these characteristics are implied in Foucault's conception of discourses: 'ways of constituting knowledge, together with the social practices, forms of subjectivity and power relations which inhere in such knowledges and relations between them' (Weedon 1987, p. 108). A social policymaker frequently faces serious problems here. He or she may find that a seemingly isolated phenomenon has a wider support network than appeared at first glance. Further, he or she may be a beneficiary with vested interests in maintaining the underlying status quo that the social problem derives from. While oriented professionally to finding solutions, as a beneficiary of the underlying power equations he or she may be prone to touch only the symptoms and not the causes.

\section{Three required activities in effective re-framing of social policy issues}

To effectively counter the framing in a long established power discourse, several activities are needed. Starting from the well known three 'core framing tasks' identified 
by Snow \& Benford (1988; also Benford \& Snow 2000), we will highlight and elaborate certain aspects: identification of a 'master frame' or discourse underlying a problematic pattern of behaviour; and presenting a persuasive alternative that captures and holds attention and is perceived as legitimate.

Firstly, the policymaker has to not just understand the facts and statistics of the present situation but place them within a larger context, including of the underlying assumptions and hypotheses in the established discourse. This corresponds to a broad interpretation of diagnostic framing - the 'identification of a problem and the attribution of blame or causality' (Snow and Benford 1988, p. 200). One must understand the problem and its causality as including the mental frames that sustain them.

Secondly, the policymaker must proceed to prognostic framing which 'involves the articulation of a proposed solution to the problem, or at least a plan of attack, and the strategies for carrying out the plan' (Benford and Snow 2000, p. 616). The proposed destination and action strategy must be based on a convincing reframing of the situation, that includes not just conscious critique of the diagnosed problematic discourse but proposed alternatives or modification to it; for example, through what we can call 'value amplification', in other words highlighting hitherto recessive values inherent in the foundational discourse itself.

Value amplification is an example of broader activity, called in the literature 'frame amplification' (but perhaps better called simply 'amplification'): the selection and highlighting of 'some issues, events, or beliefs as being more salient than others. These punctuated or accented elements may function...much like synecdoches, bringing into sharp relief and symbolizing the larger frame or movement of which it is a part. Movement slogans such as "Liberté, Fraternité, Egalité," "Power to the People," "We Shall Overcome," and "Homeless, Not Helpless" illustrate this function.' (Benford and Snow, 2000: 623). Frame amplification's partner, the other essential element in frame construction, is 'frame articulation' to knit together the highlighted elements.

Thirdly, the policymaker must be able to build a support group, using cohesive arguments that contain facts, value content and emotional force, and forming a sufficient power base to counter the power base of opposing groups. This corresponds to 
motivational framing wherein a 'vocabulary of motives' that build support and help to achieve goals is formulated (Benford and Snow, 2000: 617).

In long established discourses such as around gender, the frames may have become over time implicit and assumed as obvious, natural, inevitable. All that stand exposed in the present are a taken-for-granted 'conventional wisdom' and a set of practices deriving from the hidden frames and discourse. Thus, in India, the practices relating to celebration of the birth and life of a girl and a boy are visible and accepted, whereas the beliefs underlying why the birth of a boy is an uncomplicatedly joyous occasion, and why the birth of a girl can bring forth emotions ranging from joy to grief and anger, are more hidden. There may be economic reasons for such attitudes - a boy will contribute to the earnings of the family; a girl either will not earn or will earn for her husband's family. Further, in the absence of widespread and sufficient pension schemes parents typically rely on a son to care for them in old age, so that the monies invested in upbringing may garner returns with a boy but represent only payouts in the case of a girl. There may be cultural reasons - a boy carries forward the family name and pride, while a girl will 'belong' to her husband's family and cannot carry forward her natal family's lineage; yet the family's honour is vested with the girl and any misdeed on her part can bring dishonour not only to her immediate family but the whole extended family and community. There may also be biological reasons - a girl is felt to need more protection since she is physically weaker than a boy. Together these beliefs generate practices that perpetuate and reinforce the grounding belief. Where and when and why this kind of discourse was first produced, and what root causes led to its widespread acceptance, are often unclear and faded with time. The outcome of the discourse - that men and women are considered very different, with men seen as in general superior to women - continues as a widely accepted 'conventional wisdom'.

The implicit and diffuse nature of the foundational discourse supports the existing power relations, for no single argument can easily counter a whole set of internalised beliefs and destabilise longstanding power equations. Hence activity one in a process of successful social policymaking involves understanding not only the facts of the social issue that is to be acted upon but also the hidden discursive elements from which the existing set-up draws power. Once it has been accepted that deliberate restructuring 
strategies-'strategies that work away from the perpetuation of systematic racial, sexual and economic domination' (Forester 1989, p. 61) - are required, activity two involves consideration of possibilities for restructuring those key discursive elements.

Frame credibility is a function of frame consistency, empirical credibility, and credibility of the frame articulators (Benford \& Snow 2000). Further, most social issues are in part an outcome of frames with very extensive scope of influence - generic frames or 'master frames'. Transforming the problematic aspects of such a frame involves considerable strategization, possibly including attacking its credibility through highlighting certain features and through use of underweighted other elements of the frame ('frame amplification') to generate different implications.

Formulating a strategy is not enough, it must be presented in a form that enhances its reception. Hood and Jackson's study of Administrative Argument warns that politically successful arguments have rarely been based simply on extensive, reliable data or careful logic and comparison with alternatives. More often, successful arguments have relied on appeals to authority of some kind, and used persuasive metaphors, proverbs and simple vivid ideas, together with selected examples and comparisons that supported the intended conclusions. These examples often take the form of easy to remember and inspirational stories and parables. Finally, the arguments were stated in terms general enough to allow different groups to interpret them differently in line with their own concerns, and hence can appeal across a wide range of interests (Gasper 2002).

Directly related to activity two is activity three - creating a powerful enough support base to sway power away from the groups who enforce the practice that is to be changed. Snow and Benford (1988; Benford and Snow 2000) speak here of 'frame resonance'. To turn potential supporters into actual supporters, the frame must resonate with their worlds of experience and thought: it must deal with issues that the potential supporters have some experience of; it must appear plausible in light of that experience; and it must use themes that already exist in their culture. A further aspect, shared between activities two and three, is formulation of arguments broad enough to appeal to several different groups with partly differing agendas.

Beyond these considerations, a key question in activity three concerns the legitimacy of the policymaker's argument. In trying to change an existing social reality, 
the policymaker is effectively offering a value-laden interpretation - that the reality is 'bad'/'evil'/'immoral' (the value judgement) and must and can change (a further interpretation). The recipients of such a message can: accept both the judgement and interpretation, in which case the status quo may change; reject both, in which case nothing is likely to change; accept the judgement but not the interpretation that the situation must and can change, as may still be the case for bride burning and female infanticide in much of India; or even reject the judgement but accept the interpretation and initiate change. The response in part depends upon the perceived legitimacy of the position of each party: while the social policymaker may be backed by political legitimacy, those supporting continuation of the social practice may see their backing as deriving from cultural or religious legitimacy, which could be construed by many from those backgrounds as outranking mere political legitimacy. Thus, activity three entails more than construction of a persuasive argument; it involves creation of sufficient legitimacy, which in turn helps recruit the support of a power base sufficient to sustainably change the status quo.

The objective of the 'core framing tasks' is 'frame alignment': the making acceptable of the policymakers' framing to the target audience(s). Frame alignment not only requires communication of a valid, coherent frame but also takes account of reactions and counterframing attempts from those who are being targeted as well as those who are not directly affected but have a stake in the discourse and its power base. Benford and Snow (2000) identify the typical alignment processes as frame bridging, frame amplification, frame extension and frame transformation. Frame bridging 'refers to the linking of two or more ideologically congruent but structurally unconnected frames regarding a particular issue or problem' (p.624), and is one type of alliance building; frame extension is the extension of "primary interests to include issues and concerns that are presumed to be of importance to potential adherents' (p.625), another type of alliance building; frame amplification is 'idealization, embellishment, clarification or invigoration of existing values or beliefs' (p.624); ${ }^{\mathrm{ii}}$ and frame transformation means 'changing old understandings and meanings and/or generating new ones' (p.625). The two 'model' cases discussed in this paper will show processes of selective amplification and transformation at work, as well as elements of frame bridging and extension. We begin 
though with our central case, policy on India's 'missing girls' with special reference to Delhi state, which has been strong in none of those processes.

\section{The 'daughter deficit' in India}

Both the terms 'missing girls' and 'daughter deficit' refer to 'the gap between the number of daughters that may be expected and the number of daughters born or alive in a certain age group' (Bedi, 2008: 9). Within this, our concern is with daughter elimination, which has three components: first, female foeticide where, upon determination of the sex of the foetus, a female foetus is aborted; second, female infanticide where a female baby is killed off through a deliberate action or omission after birth (such as by drowning, poison, or allowing to die of starvation), most often in the $0-1$ age group; and third, differential mortality of male and female children, due to discrimination or neglect such as inferior nutrition or not providing medical treatment.

Daughter elimination is well documented for many parts of Asia and Africa (Aravamudan 2007; Bedi \& Srinivasan 2008; Westley \& Choe 2007, amongst others). It has strong historical roots in India, where records of female infanticide date from the $18^{\text {th }}$ century (Bedi 2008). The problem became statistically apparent in the first Indian census of 1871 where the sex ratio was 940 females per 1000 males a year after the first Act banning infanticide had already been passed by the British - the Female Infanticide Act of 1870 . In contrast to the series of enormous famines over which the British presided in India (Davis 2001), infanticide was an issue they could use to legitimate their rule.

The daughter deficit has not been confined to poorer families and in recent times has shown an increasing bias to urban areas and wealthier groups. Poorer families often do not have access to sex selection techniques such as ultrasound machines, nor can they perhaps afford such tests. As a result female infanticide is more common in more affluent rural areas, and foeticide is more prevalent in urban areas and in wealthier families who can make full use of the sex selection technologies available. Child sex ratios are also influenced by the trend towards two-child families as parents try to ensure that at least one of the two is a boy. Unsurprisingly then, the sex ratio worsens with birth order - if 
the first child is a girl, parents face pressure to ensure a boy the second time round. Some rural areas even show a trend to having a single child, a boy (ActionAid 2008).

While the proximate causes are documented and understood, deeper causes may receive inadequate sustained attention. In the state of Punjab, daughters were until a few years ago often named Veerawali: 'one who has brothers'. In a country where a book on names can be over a thousand pages long, and where names are important because they are considered to lend an aspect of their meaning to the bearer's personality, to name a girl merely with reference to her status as a sister of sons says much about her relative position. This is not an isolated example. Women across the Indian subcontinent (and in many other places) are often defined in relation to the leading men in their lives. A woman 'belongs' to her father, then her husband, and then as a widow to her son. Government forms routinely ask for the name of father/husband but rarely that of mother or wife. The jewellery a woman wears, the colours she is allowed to enjoy are directly related to her status as a wife or the mother of a son. 'May you be the mother of a hundred sons' is a common blessing even today. Unsurprisingly, then, the life of a girl carries less weight for many parents and for society than that of a boy. The 2001 Census showed an all India sex ratio in the 0-6 age group of 927 girls per 1000 boys. This marks a decline from 945 per 1000 in the 1991 Census. The lowest such sex ratio in 2001 was in Punjab (one of India's richest states) with 798 girls per 1000 boys - down from 875 in 1991. The all-India sex ratio at birth had fallen to 876 girls per 1000 boys in 2001-3 (Bedi 2008, p. 3).

A Working Group on Development of Children for the Eleventh Five Year Plan (2007-12) was set up by the Planning Commission of India to review existing approaches and programmes of protection, welfare and development of children and to make recommendations. One of its subgroups dealt with what is discussed in India as 'protection of the Girl Child'. The Working Group confirmed that 'The sharp decline in female sex ratios over the years suggests that female foeticide and infanticide might be primarily responsible for this phenomenon followed by general neglect of the girl child' (Working Group, p.6). Another recent study (ActionAid UK, 2008) suggests that the child sex ratio continues to worsen, though precise all-India figures will only emerge from the Census of 2011. 


\section{Attempts to remedy India's daughter deficit}

Most policy in India on the daughter deficit has remained limited to 'carrots' and 'sticks': financial incentives and criminalization. This continue even in the recent initiative in Delhi.

The stick: punitive \& deterrent policy interventions

One major policy intervention is the Prenatal Diagnostic Techniques (Regulation \& Prevention of Misuse) Act of 1994. This was a result of the perception that 'while preference for male child has always been a part of the society, non-invasive and instant sex determination through modern medical technology has made the elimination of girls in the pre-conception and early stages of conception easier... the increase in rate of female foeticide is a result of the greed and unethical practices of the medical community.' (Working Group on Development of Children, 2007, p.57). In 2003 a more comprehensive amended act was introduced - the Preconception and Prenatal Diagnostic Techniques (PNDT) Act. This made it illegal to disclose the sex of a foetus, in order to prevent parents from deciding on that basis to get an abortion. As the Working Group Report explained, the 'practice of infanticide has been present...but this practice did not reach the alarming proportions in elimination of girls as the present day availability of sex determination followed by sex selective abortion is reaching. This is because in foeticide, there is no inhibition from actually killing a child that an act of infanticide would involve.' (p.57). The Act has provisions for regulation and monitoring of the use of ultrasound machines and contains penalties for misuse. It seeks to punish doctors who use the available technology for sex determination; but it attempts to do this through a, in practice, very slow and cumbersome legal process. Consequently, three major new stakeholders have been created - doctors, lawyers and the police. Enforcement of the Act varies from state to state. 'Unfortunately, the existing provisions and current implementation mechanisms have failed to make any significant impact on the rising trend of female foeticide.' (p.191, Working Group on Development of Children). 
The carrot: financial and other incentives

The Working Group also recommended introduction of schemes for conditional cash and non-cash transfers 'to the family of the girl child (preferably the mother) on fulfilling certain conditionalities, for the girl child - such as birth and registration of the girl child.' (p.195). The reasoning was set out in the report - 'While the mindset towards a daughter needs to be perceptibly changed for all economic groups, however in case of less economically well off families, poverty is a huge constraint that stands in their way to raise and educate their children. Thus given a limited resource basket, these families would rather opt for a son than a daughter. In order to enable them to consciously retain their daughters, they would require financial incentives and other non cash assistance.' (Working Group on Development of Children, p.195)

Each state government was left free to take up these or any other interventions keeping in mind the particular conditions of its state. Faced with the fact that Delhi has a very adverse sex ratio ( 868 girls per 1000 boys in 2001 in the $0-6$ age group), ${ }^{\text {iii }}$ the Delhi State Government has introduced a conditional cash transfer scheme entitled the Ladli (meaning 'beloved daughter') scheme, in effect from January 2008. It had already a variety of girl protection schemes that included aspects of nutrition, education, protection from abuse etc., but these did not specifically address (or mention) foeticide or infanticide. The new scheme too states its objectives in broad terms,:-

1. To enhance the social status of a girl child in the society as well as in the family

2. To ensure proper education and make the girl child self reliant

3. To ensure economic security for the child

4. To protect the child from discrimination and deprivation.

There is again no mention of infanticide and foeticide, here or in the detailed provisions. However, the provisions on payments to be made at birth and the forfeiture clause in case of death are intended as incentives against those practices. Under the scheme, the state government promises to release grants in long term fixed deposits at key stages of the girl's life - at registration of birth, and at admission in classes I, VI, IX, X, and XII. If the child was born in hospital in Delhi, the amount is a little higher. If the girl dies before she turns eighteen, the entire amount should revert to the government. The Act is confined to 
families with income below a certain amount — even though these are not the groups with the greatest imbalance in sex-ratios - and is applicable only for two daughters per family.

\section{Impact of the carrot and stick approach}

The attempt to deal with foeticide through the 'stick' of legal measures runs independent of addressing any deeper gender bias in Indian society. Yet the PNDT Act requires the capacity and will to implement at three different levels - at the level of the medical practitioners and clinics who benefit from the black market created in sex selection technology, at the level of the police who have a multiplicity of other legislation to implement, and at the level of the legal system which is already heavily overburdened with cases. Moreover, it requires a strong monitoring infrastructure to detect when the Act is being broken. Constraints at all these levels severely limit the efficacy of the Act as a 'stick'.

The impact of the Ladli scheme as a 'carrot' has still to be fully known. But the act addresses economic issues for societal strata that are not the primary offenders: sexratio imbalance is greater amongst higher-income groups. Officials operating the scheme in Delhi believe it to be a success because of the sheer numbers of families enrolled and because the main opposition political party has copied it at municipal levels. The actual improvement, if any, in child sex ratios will be visible after the census of 2011. Given that Delhi's record in each successive census has worsened and that data for Delhi from the Office of the Chief Registrar for Births \& Deaths shows a worsening trend since the 2001 census, it is likely that impact will be rather limited even in the national capital, just as for India in total.

These two types of action - cash transfers to families with girls and strict legal action against foeticide and infanticide - have already been run concurrently for some years in certain states of India, notably Tamil Nadu. Arjun Bedi describes how the Tamil Nadu approach in fact involves more and shows how 'as in the past, daughter elimination is amenable to public policy and that a combination of legal action, economic support and intensive household level counselling and monitoring can prevent daughter elimination' (Bedi 2008, p. 27). The reference to the past is to action taken under British rule when strict legal enforcement and monitoring helped suppress infanticide or drive it 
underground. However, not only is feticide now far more prevalent than infanticide and even more difficult to combat, practices that get driven underground can resurface when the level of enforcement dies down. The attempted legal and economic solutions seem to address only the tangible manifestation but not the deep-rooted beliefs that cause the practices. Given that in much of the rest of India, including Delhi, the problem has been steadily worsening despite official application of such measures, we need to address carefully the cultural and discursive contexts in locales like Tamil Nadu where progress has been achieved, and the nature of the discursive interventions (including 'counseling of high-risk mothers', Bedi 2008, p. 26) which seem to have contributed also, not only the official carrots and sticks that are provided. ${ }^{\text {iv }}$

Carrots and sticks are both forms of conditionality, which as we saw earlier can reduce the independent commitment to and ownership of the objective by the persons supposedly being steered by these incentives. ActionAid's recent major study, for example, concludes that a change in medical ethics is essential - yet its highlighted action conclusion here is to call, in the final sentence below, for more of the stick:

The moral stance adopted by the medical fraternity is itself a matter of major concern, and there will be little success in curtailing their role unless they accept that sex selective abortion is unethical. Interviews with doctors revealed a divided opinion; many argued that if girls were not wanted they should not be born; others argued that elimination of girl children helped the larger goal of population reduction, having imbibed the official idea that small families are good both for individuals and for the nation. Others talked about providing a needed social service to people and allowing them to exercise their choice. The collusion of the medical community with providers of technology and users of technology is well documented in the literature. Hence, to effect any change measures have to be taken on all fronts by targeting and prosecuting offending practitioners. (ActionAid 2008, p. 63)

\section{Understanding policy on 'missing girls' as also an exercise in discursive politics}

From comparing districts in Tamil Nadu, Bedi and Srinivasan (2008, p. 29) conclude that "legal action against infanticide and state-wide schemes [especially offering cash incentives, equivalent to the Ladli schemes in other states]...without being linked to a grassroots monitoring and counseling approach ....and the participation and mobilization of the district administration [are] unlikely to lead to a reduction in the female deficit'. 'Mobilization of the district administration' also increases mobilization of the district populace and mobilization of normative pressure against daughter 
discrimination. We argue similarly, for feticide, that cash carrots and legal sticks are likely to be far from sufficient.

The 'daughter deficit' is connected to the frames that help create identity and power in the society it exists in. How can policymakers impact the power discourse underpinning infanticide and foeticide? Government reports recognise the deeper roots of the issue - 'the whole issue of selective elimination of females has to be understood in the wider perspective of gender issues and in the context of increasing violence against women and girls and child protection' (Sub Group Report on Child Protection: p. 22). There is recognition of a world-view in which boys are prioritised over girls. Yet there is little or no attempt to challenge this underlying discourse or to construct a new or modified meaning.

Part of the problem is that female infanticide and foeticide are but one set of practices deriving from the underlying gender discourse. Further, the policymaker, whether male or female, is typically a product of the discourse, inasmuch as (s)he has internalised many basic assumptions of the discourse and has in all probability benefitted from one or more set of social practices arising from the discourse, including forms of marriage, forms of social kinship, own identity, etc. For this reason, it is crucial to differentiate between (a) the social practices that cause harm and the supporting elements of the power discourse, and (b) those practices which are largely beneficial and widely accepted. By merely noting the deeper discourse without highlighting the elements of meaning to be added or changed, the policies leave proponents either to continue to accept the underlying discourse while fighting its physical manifestations or to unwisely attack the underlying discourse as a whole and all its many supporters.

\section{Learning from Gandhi's Salt March}

'In a political environment, the advocates of reform need to employ strategies to overcome the scepticism of others and persuade them of the importance of reform' (Cox 2001, p. 475). A social policymaker has to produce and maintain meaning 'for constituents, antagonists, and bystanders or observers' (Benford and Snow 2000, p. 613) in such a way as to persuade each of these to support her point of view. Arguably, two of 
the most successful examples of such production of meaning are Gandhi's strategy in India's independence struggle and the US anti-segregation movement of the 1950s and $60 \mathrm{~s}$.

At the time that Mohandas Karamchand Gandhi entered the Indian political scene around 1915, the British had been ruling most of India for over a century. Both political power and economic prosperity shifted from the elites of India to the elites of Britain, justified by a mental frame of moral and civilisational superiority on the basis of race. British rule in India was part of a worldwide phase of European expansion and domination that bred a sense of racial superiority. Bringing civilisation to the less developed world was a part of the 'white man's burden', in Rudyard Kipling's words. At the same time and in the same spirit, a United States senator declared colonisation 'the mission of our race, trustees under God, of the civilization of the World' (in James 1994, p. 201). As late as 1931, Winston Churchill declaimed that if the British left then 'India will fall back quite rapidly through the centuries into the barbarism and privations of the Middle Ages'.

The freedom movement started well before Gandhi's entry on the Indian political scene but he was substantially responsible for reframing the movement and bringing India to independence in relatively peaceful fashion. On January $26^{\text {th }} 1930$, Gandhi declared the goal of his struggle as 'Poorna swaraj' or complete independence. He set in motion a campaign of civil disobedience towards all the institutions and laws put in place by the British. The campaign was launched through the Dandi Salt March of March to April 1930.

Salt is found all along India's immensely long coastline. However, under the British Salt Act of 1882 the government of British India had a monopoly on its sale and production. For anyone not approved by the government, producing or selling salt was a criminal offence. The salt was taxed and the revenues thus went to supporting British rule. On March 2, 1930, Gandhi wrote to the British Viceroy of India, Lord Irwin: 'I regard this tax to be the most iniquitous of all from the poor man's standpoint. As the independence movement is essentially for the poorest in the land, the beginning will be made with this evil' ${ }^{\text {vi }}$ On March $12^{\text {th }}$ 1930, the sixty year old Gandhi and seventy-eight followers set out from the city of Ahmedabad towards the coastal town of Dandi, some 
240 miles away. The march took twenty-three days and in each village through which they passed they gained more followers (Jack 1956). On $6^{\text {th }}$ April, Gandhi picked up a lump of mud and salt from the beaches of Dandi, boiled it in seawater and thus made the illegal substance - salt. As he picked up the salt, Gandhi said 'with this, I am shaking the foundation of the British Empire'.

The Salt March produced no instant transition. Full independence of India took seventeen years to arrive. Yet a decisive shift had occurred. The Salt March had captured the imagination, nationally and worldwide. Gandhi was Time Magazine's Man of the Year for 1930. Although he was was arrested in May and jailed, the civil disobedience movement continued on a huge scale. He was fairly soon released to participate in talks on the future of India, and for the first time the Viceroy met him as an equal, as reflected in the name of the pact they arrived at, the Gandhi-Irwin pact of 1931. The partial shift of moral and political authority was what Winston Churchill famously reacted against, declaring that it was 'alarming and also nauseating to see Mr. Gandhi...striding half naked up the steps of the viceregal palace to parley on equal terms with the representative of the King-Emperor' (cited by Best 2002, p. 135). The pact led eventually to the 1935 Government of India Act which provided for a substantial degree of self-government and paved the way for an eventual rapid transfer of power after World War II.

The Salt March was a microcosm of successful social policymaking through reframing. First and foremost, salt, like many other social issues, was both a problem in itself and a symptom of a deeper societal power discourse. Gandhi understood and dealt with it accordingly. He explicitly linked the 'evil' of the salt tax to the independence movement and the end of British rule in India.

Secondly, he used the same arguments made by the British to maintain their rule and reframed them to suit his own purpose; an example of 'frame transformation'. The British spoke of 'bestowing liberty, justice and education in India...to emancipate it from the shackles of caste and prejudice' (James 1994, p. 415). Gandhi said 'Freedom is a gift of God - the right of every nation', and he presented - in contrast to the British — detailed constructive programs for bringing education to all and changing caste prejudices, that drew on Western notions of liberty, fraternity and justice for all. He drew on the 
intellectual legitimacy of that language, used by the British to justify their rule, and redirected it towards different conclusions and practical action.

Thirdly, his arguments were part of a crafted strategy of persuasion. In challenging the deeper discourse, he picked an issue that was easily understandable and appealed to every person, allowing high frame resonance. 'Every peasant and every aristocrat' understood the necessity of salt in everyday life (Copley 1987, p. 46). Thus, remarks Copley, salt was an issue that alienated no important power bases but was of sufficient importance to mobilise a mass following, appealing across religious, regional, class and ethnic boundaries. Where he implemented his strategy was equally important. The campaign took place in areas where Gandhi's personal support base was strongest. The three-week duration of the March deliberately allowed the media, public and world opinion to catch up with events and be ready for the grand finale. The events of the March were vivid and symbolic, from the long progress past cheering villagers towards the coastline, to picking up and boiling a lump of salt, contributing to capture of the world imagination.

Finally, he gave his arguments ethical legitimacy by explicitly using ethical values to justify his strategy and tactics. He highlighted values both from British liberal philosophy and from Indian traditions, thus engaging in both 'frame amplification' and 'frame bridging'. Regarding the Salt March, he wrote in his letter to the Viceroy, 'I hold British rule to be a curse, but do not intend to harm a single Englishman.' Lawrence James observed: 'For generations the British people had assured themselves that they ruled India with the consent of its people, an assumption which meant that they could accept the idea of empire with good conscience. If, as Gandhi intended, thousands, perhaps millions of Indians signified, in the gentlest possible way, that this was no longer so, then the ethical base of the raj vanished.' (James, 1994: 416). Critics have suggested however that his frame amplification of Hindu tradition-'idealization, embellishment, clarification or invigoration of existing values or beliefs' - was so emphatic that it could compromise the longer-term frame transformation of social practices that he hoped for after independence- - changing old understandings and meanings and/or generating new ones'. 


\section{Learning from Martin Luther King and the American civil rights movement}

During most of the $20^{\text {th }}$ century in the United States, another epic struggle against prevailing power discourses took place. Between 1876 and 1965, a series of laws (the 'Jim Crow laws') were enacted and applied in the Southern USA, which mandated racial segregation in all public places including schools, public transport and restaurants. One of the rationales given was that having blacks in white schools would mean 'constantly subjecting them to adverse feeling and opinion' (Murphy 1910, p. 37). In December 1955, Rosa Parks, an African American civil rights activist, refused to give up her seat on a bus in Montgomery, Alabama, even though the driver demanded the seat for white passengers. Her arrest led to the Montgomery Bus Boycott, a campaign against segregation on public transport. One of the leaders of this movement, catapulted to national fame through the campaign, was Martin Luther King Jr. In 1963, King was one of the organisers of a March on Washington for Jobs and Freedoms, at the culmination of which on $28^{\text {th }}$ August he delivered his most famous speech, 'I have a dream'. ${ }^{\text {vii }}$ He was Time Magazine's Man of the Year for 1963 and a year later won the Nobel Peace Prize.

The March on Washington for Jobs and Freedoms was organised by several civil rights groups and had six main goals - strengthened civil rights law, a massive federal works program, full and fair employment, decent housing, the right to vote, and adequate integrated education. ${ }^{\text {viii }}$ King's speech can be seen as a defining synthesis of these varied interests and goals, not just for the March but for the entire civil rights movement. Haynes Johnson, who later won a Pulitzer Prize for his coverage of the civil rights struggle, spoke in a 2003 article of the 'genius of the speech' that talked of 'all Americans of all races, of all colors, of all backgrounds' and of how King challenged people to live up to the 'emblems of the country - the Constitution, the Bill of Rights, the moral teachings' ix King employed also the Bible, Lincoln's Gettysburg address and the Emancipation Proclamation, texts holding cultural and religious sanctity for Americans.

The pattern is the same as in the Salt March. The problems, including access to jobs and public facilities, were symptoms of a deeper power discourse in American society. King addressed the deeper discourse by making the problems symbols of religiously illegitimate racial injustice - Now is the time to rise from the dark and 
desolate valley of segregation to the sunlit path of racial justice. Now is the time to lift our nation from the quicksands of racial injustice to the solid rock of brotherhood. Now is the time to make justice a reality for all of God's children'.

He engaging also in 'frame bridging', employing a second language deeply entrenched in American identity, the language of the era of the American independence struggle, including from the Bill of Rights and the American Constitution. The American Declaration of Independence stated that 'We hold these truths to be self-evident, that all men are created equal, that they are endowed by their Creator with certain unalienable Rights, that among these are Life, Liberty and the pursuit of Happiness... That to secure these rights, Governments are instituted among Men, deriving their just powers from the consent of the governed. That whenever any Form of Government becomes destructive of these ends, it is the Right of the People to alter or to abolish it, and to institute new Government...' ${ }^{\mathrm{x}}$ King added a layer of meaning to the central term 'Men', including Blacks in its ambit; and presented the civil rights movement as righteously grounded in America's foundational principles. He enlarged their 'self evident truths' by extending values such justice and liberty to Blacks as well as Whites; a 'frame extension' for blacks and 'frame transformation' for some whites. Thus he mobilised legitimacy through existing moral and ethical frames, to support inclusion of non-whites and 'to demand the riches of freedom and the security of justice ... we will not be satisfied until justice rolls down like waters, and righteousness like a mighty stream'.

The speech was full of symbolism easy to understand and relate to. It was made at a high profile event receiving worldwide attention. King's broadbased appeal sought to transcend differences of interests and bring all people together (though one may remark that it did not emphasise women), as in his famous final call: 'Let freedom ring. ... And when this happens, and when we allow freedom to ring - when we let it ring from every village and every hamlet, from every state and every city, we will be able to speed up that day when all of God's children-black men and white men, Jews and Gentiles, Protestants and Catholics - will be able to join hands and sing in the words of the old Negro spiritual: "Free at last! Free at last! Thank God Almighty, we are free at last!" 


\section{Comparative analysis}

In the activities of policymaking that we discussed earlier, activity one or diagnostic framing involves two sub-processes. First is understanding of the issue in its own right, with supporting data, identifying directly causative factors and stakeholder groups including oppositional groups. Second is to build an understanding of the larger context involving recognition and explication of the underlying dominant discourse and its sources of legitimacy; and an understanding of the different kinds of power available with different stakeholders, especially the kinds of power behind the oppositional groups (military, political, religious or cultural).

In both the model cases the understanding of issue and discourse was comprehensive enough to allow the issue to be used as a reflection of the elements of the underlying discourse that should be changed. In doing so, Gandhi and King achieved two important objectives. Firstly, they contained the attack on the underlying discourse and power system to only certain fronts. But simultaneously, their presentation of the highlighted issue as representative of matters of more general principle allowed appeal to groups who may not have suffered from the specifics of the issue at hand, but could relate to larger themes of suffering arising from exploitation or discrimination. Secondly, by focussing on discursive elements, they managed to take blame away from individuals or groups and invest responsibility in an impersonal discourse - of which some groups could be beneficiaries without having caused the discourse itself. This allowed room to save face for the groups whom they opposed. Similarly, in both cases the successful reframing helped identify a clearcut enemy or opposition - but as a negative value of injustice or discrimination rather than a racial or national group. In the 'daughter deficit' case there is a need to comparably highlight negative values inherent in the dominant master frame of gender inequality. Current state policy focuses on undesirable symptoms, treated in isolation, when it could perhaps more effectively tackle the issue by turning it into a symbol of a larger struggle against those negative values and so promote and obtain more support from civil society movements concerned with a range of related issues. 
Regarding activity two (and also three), the construction of arguments and strategies for a particular direction of change, both Gandhi and King used a mixture of themes: partly grounded in the values declared by the groups whom they opposed, thereby appealing to both their hearts and reason, while simultaneously using symbols (like salt) and metaphors (like justice as a mighty waterfall) to mobilise their own followers and inclusive language to generate interest and appeal to observers. This was buttressed by use of high attention events in high support areas and effective contacts to mass media.

Regarding activity three, the building of legitimacy and authority, there was constant reference to larger 'self evident truths' - moral stances of peace and nonviolence, implying thereby the use of violence on the part of the groups whom they opposed. Authoritative religous and cultural texts were referenced and highlighted. The struggle was presented as not between two peoples or races or countries but in terms of right and wrong, good or evil. This led many who may by race or colour or national identity have been on the opposite side to them, to extend support on moral grounds to the causes espoused by Gandhi and King.

Contrasting these model elements with those of the Indian daughter deficit case brings out significant differences. In the Indian case, policymakers have a grasp of the underlying power discourse but the issue of daughter deficit is treated in isolation rather than as an example of elements of an underlying discourse that need to be changed. The specifics of the problem issue are well documented and understood. However the absence of linkage made between the practice and the underlying discourse reduces the chance of mobilising broader support groups, such as women's groups who oppose child marriage, bride burning, domestic abuse and other such practices.

Again, by focussing not on discursive elements as causative factors but only on people who are seen as actual or potential offenders, the policy can alienate powerful groups such as doctors by statements such as we saw earlier: 'the increase in rate of female foeticide is a result of the greed and unethical practices of the medical community’ (Working Group Report on Development of Children, p. 57). Instead of a crafted 'motivational framing' the policy stumbles into motivational mis-framing. Criminalization makes three major new stakeholders all potentially culpable - doctors, 
lawyers and the police - each of whose support is needed, each of whom have much else to do and other pulls upon them. The policy creates no new motive force, other than a now long discredited fear.

Another difference between the model cases and the 'missing girls' case is in the use of evocative and powerful imagery, symbols and metaphors to draw attention and build identification amongst different interest groups. Gandhi's use of salt as a symbol of oppression and empowerment is matched by King's language of a dream, the solid sunlit path of progress, and the ringing of the freedom bell. This can be contrasted with the 'demographic' style of speech used in India in and around policy to counter female infanticide and feticide. The main terms used are 'missing girls' or 'daughter deficit', neither of which raises questions of the sanctity of life or loss of female life through deliberate acts. 'Missing girls' is used for example in posters and media campaigns in Delhi concerning foeticide and infanticide. The word 'missing' is defined by the Merriam-Webster Online Dictionary as absent or lost. It predisposes to a legal and/or police solution, and implies something to be regretted and grieved over but not the need for urgent, fundamental reform. Similarly the use of a demographic or non-moral term, 'deficit', to describe what is often arguably an act of murder reduces the urgency of the situation, reduces the possibility of popular media attention and makes a legal and incentive based solution the fitting response.

'How we define the initial problem directs us to the course of action espoused...it sets the agenda, imposes constraints on actions to be entertained or ignored, and determines the normative judgements to be made - and even the appropriate emotions to be felt.' (Miller 1985, p. 199). In the 'missing girls' case the social issue is framed as primarily a demographic one, with humanitarian overtones, rather than as centrally a humanitarian one with demographic overtones. This frame generates the strategies of focussing on the symptomatic issues rather than explicitly addressing and countering the underlying power discourse, and of not seeking to broaden the support base by use of high attention events, persuasive symbols and metaphors, and reference to higher ethical values.

Activity three addresses the problem of legitimacy. The 'daughters deficit' policy does not reference religious or cultural texts to provide legitimacy for its position against 
a lower status for women and the consequent killing of infant girls and termination of female foetuses. It does not use terms such as 'murder' or 'genocide' implying a humanitarian crisis. It relies almost entirely on state-based political legitimacy with only a background implied moral legitimacy, from an unstated assumption that discrimination and killing of one human being by another are wrong. It does not engage then with the counterclaims to legitimacy that sustain the practices that it seeks to eliminate.

In summary, we can compare the cases as follows:-

\begin{tabular}{|c|c|c|}
\hline Type of action & The Gandhi and King 'models' & $\begin{array}{l}\text { Indian state measures against } \\
\text { daughter deficit, esp. in Delhi }\end{array}$ \\
\hline $\begin{array}{l}\text { Grasp of immediate } \\
\text { issue }\end{array}$ & Comprehensive & Comprehensive \\
\hline $\begin{array}{l}\text { Grasp of causal } \\
\text { context }\end{array}$ & Comprehensive & $\begin{array}{l}\text { Recognition of context is present in } \\
\text { some texts but is not reflected in the } \\
\text { scope of action }\end{array}$ \\
\hline $\begin{array}{l}\text { Addressing } \\
\text { contextual power } \\
\text { relations and power } \\
\text { discourse }\end{array}$ & $\begin{array}{l}\text { Clear and direct address, by drawing } \\
\text { attention to the larger context and } \\
\text { explicitly countering it. }\end{array}$ & $\begin{array}{l}\text { The power context is only diffusely and } \\
\text { indirectly addressed and only implicitly } \\
\text { countered. }\end{array}$ \\
\hline $\begin{array}{l}\text { Attribution of } \\
\text { blame/causality }\end{array}$ & $\begin{array}{l}\text { - No focus on blame and no specific } \\
\text { individual or sub-group is targeted even } \\
\text { when an identification of oppositional } \\
\text { group is made ('British Empire' or 'pro- } \\
\text { segregation whites'). } \\
\text { - Emphasis on peaceful resistance, on } \\
\text { non-violence; implies presence of } \\
\text { violence on the other side and thus } \\
\text { adoption of the higher moral ground. }\end{array}$ & $\begin{array}{l}\text { - Blame laid on doctors, legal and police } \\
\text { systems, parents. } \\
\text { - Only emphasises punitive legal actions } \\
\text { (use of state force) or monetary } \\
\text { motivations. Little attempt to gain the } \\
\text { higher moral ground. }\end{array}$ \\
\hline $\begin{array}{l}\text { Reframing of } \\
\text { predominant } \\
\text { relevant discourse } \\
\text { and use of 'value } \\
\text { amplification' for } \\
\text { transformation } \\
\text { (building on values }\end{array}$ & $\begin{array}{l}\text { Use of constitutional and moral } \\
\text { discourses that were valued by the } \\
\text { opposing group, to counter the power } \\
\text { discourses of 'white man's burden' and } \\
\text { white superiority. } \\
\text { Clear amplification of ethical values of } \\
\text { justice, freedom for all, equality - which }\end{array}$ & $\begin{array}{l}\text { No reference to the values of the } \\
\text { predominant power discourse but } \\
\text { instead attempts to create a carrot and } \\
\text { stick approach (legal punishments and } \\
\text { economic incentives) to bypass the } \\
\text { power discourse. }\end{array}$ \\
\hline
\end{tabular}




\begin{tabular}{|c|c|c|}
\hline $\begin{array}{l}\text { declared in the } \\
\text { dominant frame but } \\
\text { too little applied) }\end{array}$ & $\begin{array}{l}\text { are extended to include more groups in } \\
\text { the existing discourse. } \\
\text { 'Bridging': appeal to multiple } \\
\text { legitimating discourses. }\end{array}$ & \\
\hline Style of campaign & $\begin{array}{l}\text { Use of symbols, metaphors, reference to } \\
\text { cultural and religious texts, high } \\
\text { attention events. }\end{array}$ & $\begin{array}{l}\text { No use of symbols, metaphors, } \\
\text { reference to cultural or religious texts, } \\
\text { or high attention events. }\end{array}$ \\
\hline $\begin{array}{l}\text { Action towards } \\
\text { potential support } \\
\text { groups }\end{array}$ & $\begin{array}{l}\text { Broad based, seeking to minimize } \\
\text { alienation of important groups. } \\
\text { Deliberate use of popular media to focus } \\
\text { on arguments to gain wider support. }\end{array}$ & $\begin{array}{l}\text { Narrowly issue-specific. Alienation of } \\
\text { important stakeholder groups such as } \\
\text { doctors and police. Little deliberate use } \\
\text { of popular media to present arguments } \\
\text { or gain wider support/awareness. }\end{array}$ \\
\hline $\begin{array}{l}\text { Means used to } \\
\text { access legitimacy }\end{array}$ & $\begin{array}{l}\text { Authoritative religious and cultural } \\
\text { texts; explicit moral power. }\end{array}$ & $\begin{array}{l}\text { State-based political power and only } \\
\text { implicit use of moral power. The } \\
\text { religious and cultural authority that are } \\
\text { invoked to support the anti-daughter } \\
\text { practices are left undisturbed. }\end{array}$ \\
\hline
\end{tabular}

Gandhi, King and present day policymakers in India are all involved to some degree in attempts at frame transformation. The different degrees of success seem in part a consequence of the use of the strategies and tools of framing. Gandhi and King made conscious use of frame amplification, frame extension and frame bridging, in order to attain a frame transformation. Both leaders amplified elements existing in the dominant frame and extended their scope to groups not traditionally perceived as covered by those elements. They highlighted internal contradictions such as 'self evident' claims that were universal in theory but severely limited in actual practice. Both consciously referred to existing cultural, secular and religious values, folk narratives and extant beliefs to gain wider support and credibility for the frames they propagated. They also sought to extend the frames to include concerns (such as world peace) that were broader than the ones they sought immediately to address, thus increasing allies and legitimacy. The tools they used varied. They enhanced their frame's resonance with the experiences of the target audience by using common parlance, easily understood symbols and metaphors and elements of 'myths' relevant 
to and revered by all. In contrast, policymakers in the Delhi case have made no use of the comparable tools and strategies available.

We have presented some suggestions based on examination of two cases of successful mobilization, chosen precisely because of their success in face of great resistance. Examination of additional cases will no doubt refine and add to the analysis. Let us for the moment sum up.

Social policymakers may be constrained by lack of knowledge or access to the literatures on re-framing discourses. Similarly they may face constraints of time and from the complexities of political maneuvers and alliances, the multiplicity of actors involved and consequent multiplicity of actions to be taken account of. However, similar constraints applied for Gandhi and King. Both faced the task of creating legitimacy in a complex and partly hostile environment. Despite - and in fact because of-all this, they deliberately essayed understanding and reframing of the existing power discourses. The history of girl child deprivation, infanticide and feticide in India suggests that while temporary successes may be obtained in specific places as a result of specific local conditions, sustained change requires transformation in the underlying power discourse, and that this could be accelerated through attention to framing tools and strategies (amongst other measures, such as pension schemes). The comparison with Gandhi and King implies that notwithstanding the specificities of different social issues, attention to strategies based on amplification, extension, resonance and possible bridging of master frames may yield greater results in Indian social policy than a reliance solely on the carrot and stick approach. We in no way suggest that such strategies are easily formulated and carried out, but propose that recognition of their relevance and importance will help.

Manisha Sinha has worked in various positions in the Government of India.

Des Gasper teaches at the International Institute of Social Studies, Erasmus University Rotterdam. 
Acknowledgements: We are grateful for helpful comments on one or other earlier version from two anonymous referees, Shanti George, Ravinder Kaur, Jos Mooij and especially Sharada Srinivasan, and participants in a session at the $4^{\text {th }}$ International Conference on Interpretive Policy Analysis (University of Kassel, June 2009). The usual disclaimer applies.

\section{REFERENCES}

ActionAid, 2008. Planning Families, Planning Gender. Delhi: Action Aid/ IDRC.

ActionAid UK, 2008. Disappearing Daughters. London: ActionAid.

Aravamudan, G., 2007. Disappearing Daughters: The tragedy of female foeticide.

New Delhi: Penguin.

Ashe, G., 1968. Gandhi: A study in Revolution. London: Heinemann.

Bedi, A.S., 2008. Bare Branches and Drifting Kites: Tackling female infanticide and feticide in India. Inaugural lecture. Institute of Social Studies, The Hague.

Bedi, A.S., and Srinivasan, S., 2008. Tackling daughter deficits in Tamil Nadu, India. http://ssrn.com/abstract=1171882, Social Science Research Network.

Bemelmans-Videc, M.L.B., Rist, R.C., and Verdung E., 1998. Carrots, Sticks and Sermons - Policy instruments and their evaluation. New Brunswick, USA: Transaction Publishers.

Benford R.D., and Snow, D.A., 2000. Framing Processes and Social Movements: An Overview and Assessment. Annual Review of Sociology 26, 611-639

Best, G., 2002. Churchill: A Study in Greatness. London: Penguin.

Copley, A., 1987. Gandhi Against the Tide. Oxford: Basil Blackwell.

Cox, R.H., 2001. The Social Construction of an Imperative: Why Welfare Reform Happened in Denmark and the Netherlands but Not in Germany. World Politics, 53, 463-498.

Davis, M., 2001. Late Victorian Holocausts. London: Verso.

Ellerman, D., 2006. Helping People Help Themselves. Ann Arbor: Univ. of Michigan Press.

Forester, J., 1989. Planning in the Face of Power. Berkeley: Univ. of California Press. 
Gasper, D., 2002. Fashion, Learning and Values in Public Management. Africa Development, 27 (3), 17-47.

Glegg, S., 1998. Foucault, Organization and Power. In: Grant, D., Keenoy, T. and Oswick, C., eds., Discourse + Organization, London: Sage, 29-48.

Hood, C., and Jackson, M., 1991. Administrative Argument. Aldershot, UK: Dartmouth Publishing Co..

Jack, H.A., 1956. The Gandhi Reader: A source book of his life and writings. Bloomington: Indiana University Press.

James, L., 1994. The Rise and Fall of the British Empire. London: Little, Brown \& Company.

Miller, D.F., 1985. Social policy: An exercise in metaphor. Knowledge: Creation, Diffusion, Utilization, 7 (2), 191-215.

Murphy, E.G., 1910. The Problems of the Present South, New York: Macmillan.

Rem, D., and Gasper, D., 2008. Romania's accession process into the European Union -- Discourses at policy-, program-, and project- levels in the justice sector. Working Paper 463, The Hague: Institute of Social Studies.

Schön, D., and Rein, M., 1994. Frame Reflection: Towards the Resolution of Intractable Policy Controversies. New York, Basic Books.

Snow, D., and Benford, R., 1988. Ideology, frame resonance, and participant mobilization. International Social Movement Research, 1, 197-217 .

Srinivasan, S. and A.S. Bedi, 2008. Daughter Elimination in Tamil Nadu, India: A Tale of Two Ratios., Journal of Development Studies 44 (7), 961-990.

Sub Group Report on Child Protection, 2007. Child Protection in the Eleventh Five Year Plan. New Delhi: Ministry of Women and Child Development. http://wcd.nic.in/wgchilprotection.pdf

Weedon, C., 1987. Feminist Practice \& Poststructuralist Theory. Cambridge, MA: Blackwell

Westley, S.B., and Choe, M.K., 2007. How does son preference affect populations in Asia? Asia Pacific Issues, No. 84. Honolulu: East-West Center. 


\section{Working Group on Development of Children for the Eleventh Five Year Plan (2007- 12), 2007. Report - Volume One. New Delhi: Ministry of Women and Child Development. http://wcd.nic.in/WG_Report.pdf}

\footnotetext{
${ }^{i}$ See e.g. Glegg (1998) on the concept of 'discursive power', power through discourse, derived from Foucault (originally stated in his Surveiller et Punir (Paris: Gallimard, 1975)).

ii The definition Benson and Snow use a page earlier (p.623) emphasises selection amongst existing beliefs and experiences, the aspect that we underlined in the earlier discussion.

iii $h$ ttp://des.delhigovt.nic.in/Census2001/delhiglance.htm

${ }^{\text {iv }}$ In addition, the Tamil Nadu program sends a strong message in the way its cash incentives scheme is formulated: only poor families who have only daughters and no son are eligible. Tamil Nadu is notable too for a state scheme for pensions for the elderly poor. We thank Sharada Srinivasan for these points.

${ }^{v}$ http://www.winstonchurchill.org/learn/speeches/speeches-of-winston-churchill/105-our-duty-in-india.

${ }^{v i}$ http://english.emory.edu/Bahri/Dandi.html

vii $h$ ttp://www.usconstitution.net/dream.html

viii $\mathrm{http}: / / \mathrm{mlk}-$

kpp01.stanford.edu/index.php/kingpapers/article/march_on_washington_for_jobs_and_freedom

${ }^{\mathrm{ix}} \mathrm{http}: / / \mathrm{www} . p b s . o r g /$ newshour/bb/race_relations/july-dec03/march_08-28.html

${ }^{x}$ www.ushistory.org/declaration/document/index.htm
} 